\title{
Anti-inflammatory and antioxidative effects of six pentacyclic triterpenes isolated from the Mexican copal resin of Bursera copallifera
}

Antonio Romero-Estrada', Amalia Maldonado-Magaña', Judith González-Christen², Silvia Marquina Bahena', María Luisa Garduño-Ramírez ${ }^{1}$, Verónica Rodríguez-López² and Laura Alvarez ${ }^{1 *}$ (D)

\begin{abstract}
Background: Bursera copallifera (Burseraceae) releases a resin known as "copal ancho" which has been used, since pre-Colombian times, as ceremonially burned incense and to treat tooth ache, tumors, arthritis, cold, cough, and various inflammatory conditions; however, its anti-inflammatory potential is poorly studied. The aim of the present study was to isolate, quantify, and to investigate the anti-inflammatory activity of triterpene compounds isolated from the copal resin of B. copallifera.

Methods: The constituents present in the total resin of B. copallifera were obtained by successive chromatographic procedures, and quantitative analysis was performed by High Performance Liquid Chromatography (HPLC). Antiinflammatory effects of the isolated triterpenes were investigated to determine their inhibitory effects on phorbol ester 12-O-tetradecanoylphorbol-13-acetate (TPA)-induced edema in mice, viability and nitric oxide (NO) production inhibition on lipopolysaccharide (LPS)-activated RAW 264.7 macrophages, and inhibition of cyclooxygenase (COX)-1, COX-2 and secretory Phospholipase $A_{2}$ (sPLA 2 ) activities in vitro.

Results: Quantitative phytochemical analysis of the copal resin showed the presence of six pentacyclic triterpenes of which, 3-epilupeol (59.75\% yield) and a-amyrin (21.1\% yield) are the most abundant. Among the isolated triterpenes, 3-epilupeol formiate (Inhibitory Concentration $\left.50 \%\left(I C_{50}\right)=0.96 \mu \mathrm{mol}\right)$, a.amyrin acetate $\left(I_{50}=1.17 \mu \mathrm{mol}\right)$, lupenone $\left(I C_{50}=1.05 \mu \mathrm{mol}\right)$, and 3-epilupeol $\left(I C_{50}=0.83 \mu \mathrm{mol}\right)$ showed marked inhibition of the edema induced by TPA in mice. a-amyrin acetate and 3-epilupeol acetate, at $70 \mu \mathrm{M}$, also inhibited the activity of COX-2 by 62.85 and 73.28 $\%$ respectively, while a-amyrin and 3-epilupeol were the best inhibitors of the production of NO in LPS-activated RAW 264.7 cells with $I_{50}$ values of 15.5 and $8.98 \mu \mathrm{M}$ respectively, and did not affected its viability. All compounds moderately inhibited the activity of PLA .
\end{abstract}

Conclusions: This work supports the folk use of B. copallifera and provides the basis for future investigations about the therapeutic use of this resin in treating inflammation.

Keywords: B. copallifera, Copal ancho, Pentacyclic triterpenes, Inflammation, NO inhibition, COX-2 inhibition

\footnotetext{
*Correspondence: lalvarez@uaem.mx

${ }^{1}$ Centro de Investigaciones Químicas-IICBA, Universidad Autónoma del

Estado de Morelos, Avenida Universidad 1001, Chamilpa, Cuernavaca,

Morelos 62209, Mexico

Full list of author information is available at the end of the article
} 


\section{Background}

Bursera species are the dominant woody taxa in dry forests of México, where this genus reach its maximum diversity and abundance with about 84 species being present, 80 of which are endemic to the country [1-3]. These plants release a resin known as copal, derived from the Nahuatl language word "copalli" meaning incense [4]. This genus has been taxonomically related to Commiphora and Boswellia, which also produce resins known as myrrha and frankincense, respectively [5].

The resins obtained from Bursera spp. play an important role in the economy of rural families in México, and they are particularly identified with the aromatic resins used by the cultures of pre-Columbian Mesoamerica as ceremonially burned incense and other purposes. Copal is still used by a number of peoples of México and Central America as incense and during sweat lodge ceremonies, and the trees where the resins are obtained are today cultivated in many regions of México $[4,6]$. Copal, as a traditional natural medicine, has been used to treat various diseases, such as tooth ache, tumors, fever, and inflammatory conditions. Tea made with the resin is a traditional remedy as analgesic and has been used to clean wounds and sores, and to cure bronchitis, cough and rheumatism since pre-Columbian time, and it is still used [7-9].

Among various resins collected by local people of Morelos state of México, "copal ancho" (Bursera copallifera, DC, Bullock) is considered as a source of high grade copal resin, and it is commonly used against rheumatoid arthritis, cold, cough, for stroke and dental pain, and for hasten wound healing $[10,11]$.

Previous studies have demonstrated the cytotoxic activity of the chloroform extracts obtained from the stems and fruits of B. copallifera [12]. More recently, our research team showed that the hydroalcoholic extract of the stems as well as the dichloromethane: methanol extract from the leaves inhibited the mouse ear inflammation in response to topical application of TPA by 54.3 and $55.4 \%$ respectively, at the dose of 0.5 $\mathrm{mg} / \mathrm{ear}$ [13]. Further, in this work, the mechanism for this anti-inflammatory effect was related to the direct inhibition of COX-1 and moderate of COX-2, which are associated with inflammatory diseases. However, the anti-inflammatory potential of the resin and its constituents are still unknown.

The ethnomedicinal importance of B. copallifera and its components, prompted us to undertake detailed investigation on the constituents of the resin and their anti-inflammatory activity in order to evaluate its antiinflammatory potential and compare with those described for the other parts of the plant. Although the TPA-induced mouse ear model of inflammation is nonspecific, it is widely used for acute anti-inflammatory screening because TPA activates PLA , $[14]$ and the resulting edema is primarily mediated by prostaglandin E2 (PGE2) [15]. Thus, both $\mathrm{PLA}_{2}$ and COX are involved in this model, and it has been demonstrated that the organic extracts of $B$. copallifera interfere with these enzymes to inhibit TPA-induced inflammation.

In this paper, we report the isolation and identification of six triterpenes (1-6) with anti-inflammatory activity, isolated from the $n$-hexane soluble fraction of the resin of B. copallifera. In addition, quantification of the active components in the resin was also performed by HPLC analysis. The anti-inflammatory activity of the six isolated compounds was evaluated in the mice model of TPA-induced edema. Furthermore, we examined the inhibitory effects of these triterpenes on cell viability and NO production in LPS- stimulated RAW 264.7 macrophages. Also, their inhibitory effects over COX-1, COX-2, and $s \mathrm{PLA}_{2}$ activities in vitro were assayed.

\section{Methods \\ Materials and reagents}

Silica gel (70-230 mesh, ASTM and 230-400 mesh) and Preparative Thin Layer Chromatography (TLC) were purchased from Merck. Deuterated chloroform $\left(\mathrm{CDCl}_{3}\right)$, TPA, indomethacin, LPS from Escherichia coli serotype 055:B5, sodium nitrite $\left(\mathrm{NaNO}_{2}\right), \mathrm{N}$-(1-naphtyl) ethylenediamine dihydrochloride and sulfanilamide were purchased from Sigma Aldrich. Dulbecco's Modified Eagle's Medium/Nutrient Mixture F-12 (DMEM/F12), fetal bovine serum (FBS) and Glutamine (GlutaMax) were from GIBCO, [3-(4,5-dimethyl-2-yl)-5-(3-carboxymethoxyphenyl)-2-(4-sulfophenyl)-2H-tetrazolium, inner salt; MTS] was from Promega Co. s $\mathrm{PLA}_{2}, \mathrm{COX}-1$ and COX-2 ELISA kits were purchased from Cayman Chemical Co.

\section{Plant material}

The resin of B. copallifera (DC.) Bullock was collected in August 2011 at El limón de Cuahuchichinola (N 18 31'16.5”), in the Reserva de la Biósfera Sierra de Huautla (REBIOSH) by M. C. Teresita Rodríguez López. Voucher specimen No. 31809 was deposited at the Herbarium of the University of Morelos (HUMO) in the Centro de Investigación en Biodiversidad y Conservación (CIByC) at the Universidad Autónoma del Estado de Morelos (UAEM).

\section{Compound isolation}

The resin of $B$. copallifera was air-dried at room temperature for 4 weeks, ground and homogenized to an uniform powder by ceramic mortar with pestle. $20 \mathrm{~g}$ of the resin powder was totally dissolved with $50 \mathrm{~mL}$ of a mixture of dichloromethane:acetone (9:1) at room temperature and subjected to column chromatography (CC) on $150 \mathrm{~g}$ silica gel (70-230 mesh, ASTM), and 
stepwise gradient elution with $n$-hexane:acetone $(1: 0 \rightarrow 1: 1$, $\mathrm{v} / \mathrm{v})$. Three fractions of $1.5 \mathrm{~L}$ each were collected, $n$-hexane (F-1, $6.06 \mathrm{~g}), n$-hexane:acetone 9:1 (F-2, $8.8 \mathrm{~g})$ and $n$-hexane:acetone 8:2 (F-3, $5.1 \mathrm{~g})$.

F-1 was subjected to CC on 165 g silica gel (230-400 mesh) using a mixture of hexane:dichloromethane 95:5 as the isocratic eluent, $100 \mathrm{~mL}$ fractions were collected through-out and pooled into four groups (F1-1 to F1-4) according to composition, as visualized by TLC. F1-1 (78.2 mg) was purified by preparative TLC (n-hexane:dichloromethane 93:7) to afford $45.9 \mathrm{mg}$ of lup-20(29)-en$3 \alpha$-ol formiate (1) and $9.6 \mathrm{mg}$ of ursan-3 $\beta$-ol acetate (2), F1-2 (271.2 mg) afforded $245 \mathrm{mg}$ of lup-20(29)-en-3 $\alpha$-ol acetate (3) after acetone crystallization. F1-3 (5.4 g) was subjected to CC on silica gel (230-400 mesh), using $n$-hexane:Ethyl acetate gradient $(9: 1 \rightarrow 1: 1)$ which gave three major fractions, F1-3A (2.66 g), F1-3B (115.1 mg) and F1-3C (2.61 g). F1-3A was purified by silica gel (230-400 mesh) chromatographic column eluting with an isocratic mixture of $n$-hexane:dichloromethane (95:5) to afford $8.4 \mathrm{mg}$ of lup-20(29)-en-3-one (4), and $2.2 \mathrm{~g}$ of lup20(29)-en-3 $\alpha$-ol (5). Fraction F1-3B gave pure 5 (115.1 mg), and fraction F1-3C was purified by silica gel (230-400 mesh) CC, using $n$-hexane:Ethyl acetate (98:2) to afforded $2.5 \mathrm{mg}$ of lup-20(29)-en-3 $\alpha$-ol (5) and $0.0122 \mathrm{mg}$ of pure $\alpha$-amyrin (6). F-2 was constituted for lup-20(29)-en-3 $\alpha$-ol (5) and $\alpha$-amyrin (6) principally. The structures of isolated compounds were identified by spectroscopic and spectrometric analyses (Fig. 1). The samples were dissolved with $\mathrm{CDCl}_{3}$ and Nuclear Magnetic Resonance (NMR) spectra were acquired on a Varian Unity NMR spectrometer operating at $400 \mathrm{MHz}$ for ${ }^{1} \mathrm{H}$ and $100 \mathrm{MHz}$ for ${ }^{13} \mathrm{C}$ nuclei. For the structural determination, the experiments ${ }^{1} \mathrm{H}-{ }^{1} \mathrm{H}$ gCOSY, NOESY, gHSQC and gHMBC were analyzed as required. FABMS spectra were recorded on a JOEL JMX-AX 505 HA mass spectrometer.

\section{Quantitative analysis by HPLC}

Resin dried and pulverized (3 mg) and standards (3 mg) were prepared by sonicating $(10 \mathrm{~min})$ in methanol $(1 \mathrm{~mL})$ and analyzed by HPLC. All samples were filtered through $0.45 \mu \mathrm{m}$ syringe filter and injected into HPLC. Chromatography was carried out on a Waters 600E gradient module HPLC system, Waters 717 plus Autosampler, waters 996 photodiode array detector and computer with EmpowerPro of waters. The column used was a reversed phase Chromolith SpeedROD RP-18e (50 mm × $4.6 \mathrm{~mm}$ ), from Merck. The separation was carried out isocratically using Acetonitrile:Water (95:05) as the mobile phase (40 min). The system was operated at room temperature and monitored at $210 \mathrm{~nm}$. The flow rate was $0.5 \mathrm{~mL} / \mathrm{min}$ and the injection volume was $20 \mu \mathrm{L}$. The standard samples of lup-20(29)-en-3 $\alpha$-ol formiate (1), ursan-3 $\beta$-ol acetate (2), lup-20(29)-en-3 $\alpha$-ol acetate (3), lup-20(29)-en-3-one (4), lup-20(29)-en-3 $\alpha$-ol (5) and $\alpha$-amyrin (6) compounds were isolated from the resin of $B$. copallifera and characterized in our laboratory. The purity $(>98)$ of the isolated compounds was confirmed by HPLC and ${ }^{1} \mathrm{H}$ NMR analysis. Quantification was performed by comparing their retention times with the standards and calculating the concentration from the respective calibration curves. The assay was performed in triplicate.

\section{In vivo anti-inflammatory activity TPA-induced mouse ear edema}

Mouse ear edema was evaluated following the described protocol [16]. All experiments were carried out using six animals per treatment. Adult male CD-1 mice with a body weight ranging from 25 to $30 \mathrm{~g}$ were used. Experiments were performed according to the Official Mexican Rule: NOM-062-ZOO-1999 Guidelines (Technical Specifications for the Production,

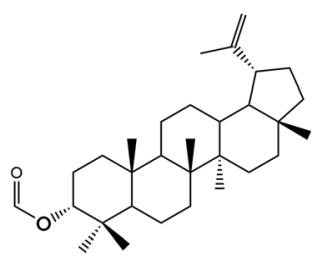

(1)

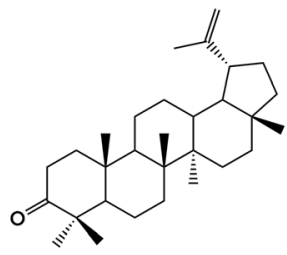

(4)

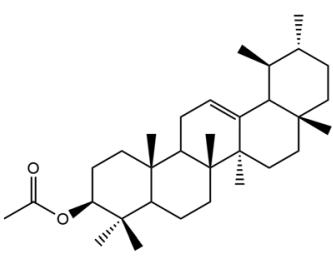

(2)

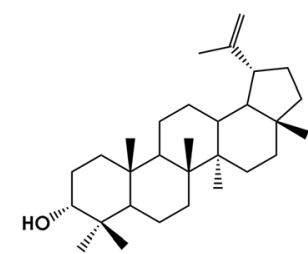

(5)

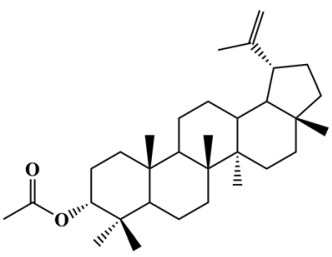

(3)

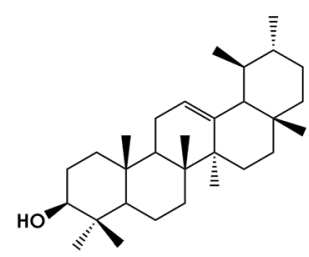

(6)

Fig. 1 Triterpenes isolated from the resin of Bursera copallifera 
Care, and Use of Laboratory Animals) and international ethical guidelines for the care and use of experimental animals. The experimental protocol followed was approved by Comité de Experimentación del Bioterio of the Universidad Autónoma del Estado de Morelos (BIO-UAEM) (Approval number: BIO-UAEM: 009:2013). Mice were maintained under standard laboratory conditions (Bioterio at the Universidad Autónoma del Estado de Morelos) at $22{ }^{\circ} \mathrm{C} \pm 3{ }^{\circ} \mathrm{C}, 70 \% \pm 5 \%$ of humidity, $12 \mathrm{~h}$ light/dark cycle and food/water ad libitum. A negative control group received acetone as vehicle and indomethacin was used as anti-inflammatory drug as positive control group. Finally, compounds were tested by separate treatment groups. Animal ear inflammation was induced with $2.5 \mu \mathrm{g}$ of TPA dissolved in $20 \mu \mathrm{L}$ of acetone applied to the internal and external surface of the right ear to cause edema. Sample doses of 1, 0.75, $0.50,0.25$ and $0.125 \mathrm{mg} / \mathrm{ear}$ of the compounds, as well as the anti-inflammatory drug of reference (indomethacin) were applied. All the samples of the different treatments were dissolved in $(20 \mu \mathrm{L}$ of acetone or ethanol) depending on the solubility of the specified compound and applied topically on the right ear immediately after TPA application; on the left ear acetone or ethanol was applied as vehicle. Four hours after application of the samples of interest as possible anti-inflammatory agents, the animals of each treatment were sacrificed by cervical dislocation. Circular sections of $6 \mathrm{~mm}$ in diameter were taken from both: the treated $(\mathrm{t})$ and the non-treated (nt) ears, which were weighed to determine the inflammation. Percentage of inhibition was determined by the formula expressed below:

$$
\text { Inhibition } \%=\left(\Delta w \text { control }-\frac{\Delta w \text { treatment }}{\Delta w}\right) \times 100
$$

where $\Delta \mathrm{w}=\mathrm{w}_{\mathrm{t}}-\mathrm{w}_{\mathrm{nt}}$; being $\mathrm{w}_{\mathrm{t}}$ the weight of the section of the treated ear and $w_{n t}$ the weight of the section of the non-treated ear. The $\mathrm{IC}_{50}$ values of the antiinflammatory activity obtained at the doses of $1,0.75$, $0.50,0.25$ and $0.125 \mathrm{mg} /$ ear were calculated using GraphPad Prism ${ }^{\circ}$ software by lineal regression analysis.

\section{In vitro anti-inflammatory activities \\ Cell culture}

Murine macrophage cell line RAW 264.7 (Tib-71tm from ATCC) were grown in DMEM/F12 medium supplemented with $7.5 \%$ heat-inactivated FBS, GlutaMax, without antibiotics. Cells were plated and incubated in a humidified atmosphere containing $5 \% \mathrm{CO}_{2}$ at $37{ }^{\circ} \mathrm{C}$. Cells were sub-cultured by scraping and seeding them in $75 \mathrm{~cm}^{2}$ flasks or 24-wells plates.

\section{Treatment of macrophages with LPS}

RAW 264.7 cells $\left(1.4 \times 10^{5}\right.$ cells/well $)$ were plated and incubated into 24-well plates in $0.5 \mathrm{~mL}$ of DMEM/F12 medium supplemented with $7.5 \%$ heat-inactivated FBS, for $24 \mathrm{~h}$, at $37{ }^{\circ} \mathrm{C}$ with $5 \% \mathrm{CO}_{2}$. After that, macrophages were incubated for two hours with the test compounds (2-6) at various concentrations $(0-70 \mu \mathrm{M})$ or vehicle (Dimethyl sulfoxide (DMSO), $0.5 \%, \mathrm{v} / \mathrm{v}$ ) or indomethacin $(30 \mu \mathrm{g} / \mathrm{mL})$. Then, macrophages were incubated with LPS $(10 \mu \mathrm{g} / \mathrm{mL})$ in the presence or absence of test compounds, indomethacin or vehicle and without LPS at $37{ }^{\circ} \mathrm{C}$ for $20 \mathrm{~h}$ to stimulate NO production. Finally, cell-free supernatants were collected and were kept at $-20{ }^{\circ} \mathrm{C}$ until NO quantification. The suppressive effect of compounds $2-6$ on NO production was assessed using the Griess reagent

\section{Determination of NO concentration}

Nitrite, the stable end product of NO, was used as an indicator of NO production in the culture medium. Nitrite released in the culture medium was measured according to Griess reaction. Briefly, $50 \mu \mathrm{L}$ of each cell culture supernatants were mixed with $100 \mu \mathrm{L}$ of Griess reagent $(50 \mu \mathrm{L}$ of $1 \%$ sulfanilamide and $50 \mu \mathrm{L}$ of $0.1 \% \mathrm{~N}$ (1-naphtyl) ethylenediamine dihydrochloride in $2.5 \%$ phosphoric acid), for $10 \mathrm{~min}$ at room temperature. The optical density at $540 \mathrm{~nm}\left(\mathrm{OD}_{540}\right)$ was measured with a microplate reader and nitrite concentration in the samples were calculated by comparison with the $\mathrm{OD}_{540}$ of a standard curve of $\mathrm{NaNO}_{2}$ prepared in fresh culture medium [17].

\section{MTS-tetrazolium salt assay}

Cell viability was measured based on the formation of blue formazan metabolized from colorless MTS by mitochondrial dehydrogenases, which are active only in live cells. RAW 264.7 macrophages were plated in 96-well plates at a density of $1.2 \times 10^{4}$ cells per well for $24 \mathrm{~h}$. The cells were treated and incubated with various concentrations of test compounds $(0-70 \mu \mathrm{M})$ for $24 \mathrm{~h}$. Cell viability was determined by MTS assay, using the CellTiter 96 Aqueous Non-Radioactive Cell Proliferation assay (Promega). Briefly, $20 \mu \mathrm{l}$ of MTS was added to each well, and the cells were incubated for another $4 \mathrm{~h}$ at $37^{\circ} \mathrm{C}$ with $5 \% \mathrm{CO}_{2}$. The optical density was measured at $490 \mathrm{~nm}$ on a microplate reader.

\section{$s P L A_{2}$ enzyme inhibitory assay}

Activity of $s P \mathrm{LA}_{2}$ was evaluated by the test described in the $s \mathrm{PLA}_{2}$ (Type V) Inhibitor screening Assay kit No. 10004883 from Cayman Chemical Co., according to the manufacturer's instructions. The compounds (1-6) at 70 $\mu \mathrm{M}$ and positive control palmitoyltrifluoromethylketone at $4 \mu \mathrm{M}$ dissolved in DMSO or ethanol were assayed. 


\section{COX-1 and 2 enzyme inhibitory assay}

All compounds described here were tested for their ability to inhibit COX-1 and COX-2 using a COX-1(ovine) and COX-2 (human)-inhibitor screening assay kit No. 701050 from Cayman Chemical Co., according to the manufacturer's instructions. The compounds (1-6) at 70 $\mu \mathrm{M}$ and selective COX-1 inhibitor, SC-560 (3.3 $\mu \mathrm{M})$ and selective COX-2 inhibitor, DuP-697 (3 $\mu \mathrm{M})$ dissolved in DMSO or ethanol were assayed.

\section{Statistical analysis}

The results shown were obtained at least by three independent experiments and are presented as means \pm SDs. Statistical analyses were performed by one-way analysis of variance (ANOVA) with Tukey's post hoc test. All statistical analyses were performed using the OriginLab (Massachustts USA), version 8.0 software. $P$ values 0.05 were considered to indicate statistical significance.

\section{Results}

In vivo anti-inflammatory activity of the resin

The resin of $B$. copallifera was dissolved with a mixture of dichloromethane:acetone $(8: 2)$ at room temperature, this extract showed inhibition on TPA-induced auricular edema in mice $\left(50 \%\right.$ inhibitory dose $\left.\left(\mathrm{ID}_{50}\right)=0.7071 \mathrm{mg} / \mathrm{ear}\right)$.

\section{Triterpenes isolation}

Repeated silica gel column chromatography of the active extract, allowed the isolation of six bioactive triterpenes. The structures of compounds 1-6 (Fig. 1) were determined using ${ }^{1} \mathrm{H},{ }^{13} \mathrm{C}$ NMR, and Mass Spectrometry (MS) data which were in complete agreement with reported ones, 3-epilupeol formiate (1), $\alpha$-amyrin acetate (2), 3-epilupeol acetate (3), lupenone (4), 3-epilupeol (5) and $\alpha$-amyrin (6) [18-24].

\section{Quantitative analysis of triterpenes by HPLC}

HPLC quantification of the triterpenes present in the total resin was performed using authentic 3-epilupeol formiate (1), $\alpha$-amyrin acetate (2), 3-epilupeol acetate (3), lupenone (4), 3-epilupeol (5), and $\alpha$-amyrin (6) as standards. The results showed that 3-epilupeol (5, 59.75 $\%)$ and $\alpha$-amyrin $(6,21.1 \%)$ are the most abundant triterpenes in the resin. The minor triterpenes were $\alpha$-amyrin acetate $(2,6.25 \%)$, 3-epilupeol acetate $(3,11.31 \%)$, lupenone (4, $1.82 \%)$, and 3-epilupeol formiate (1, $0.5 \%)$.

\section{In vivo anti-inflammatory activity of triterpenes}

The isolated triterpenes 1-6 were evaluated at different concentrations in TPA-induced auricular edema in mouse model. Table 1 illustrates the anti-inflammatory activity displayed by these compounds. Except for compounds $\mathbf{3}$ and 6, all the triterpenes showed marked anti-inflammatory activity with $\mathrm{ID}_{50}$ values ranging from 0.83 to $1.17 \mu \mathrm{mol}$.
Table 1 Effect produced by resin and pure compounds 1-6 from B. copallifera on auricular edema induced by TPA in mice

\begin{tabular}{lcl}
\hline & $\begin{array}{c}\text { Edema inhibition (\%) } \\
(1 \mathrm{mg} / \text { ear })\end{array}$ & $\begin{array}{l}\mathrm{ID}_{50} \\
\mu \mathrm{mol} / \mathrm{ear}\end{array}$ \\
\hline Total extract from B. copallifera resin & $55.14 \pm 3.85$ & $0.707^{\mathrm{a}}$ \\
3-epilupeol formiate (1) & $62.16 \pm 1.80$ & 0.96 \\
a-amyrin acetate (2) & $69.45 \pm 0.87$ & 1.17 \\
3-epilupeol acetate (3) & $49.35 \pm 3.6$ & $>2.13$ \\
Lupenone (4) & $57.25 \pm 1.36$ & 1.052 \\
3-epilupeol (5) & $66.39 \pm 4.38$ & 0.83 \\
a-amyrin (6) & $25.00 \pm 1.81$ & $>2.34$ \\
Indomethacin & $91.35 \pm 0.47$ & 0.67 \\
\hline
\end{tabular}

Data represent the mean \pm S.D. of at least three independent experiments performed in triplicate. ${ }^{a}$ The dose was in $\mathrm{mg} / \mathrm{ear}$

\section{In vitro anti-inflammatory activity of triterpenes}

The effects of triterpenes $\mathbf{1 - 6}$ on the viability of the RAW 264.7 cells was determinated at different concentrations $(4.37,8.75,17.5,35.0$, and $70.0 \mu \mathrm{M}$ ) (Fig. 2), and all the triterpenes did not exhibit a significant reduction in viability of macrophages compared con the positive control, up to the concentration of $70 \mu \mathrm{M}$.

To assess the effect of the triterpenes (1-6) isolated from $B$. copallifera resin on production of NO in LPSinduced RAW 264.7 cells, cells were treated with/without natural products $(4.37,8.75,17.5,35.0$, and $70.0 \mu \mathrm{M})$ for $2 \mathrm{~h}$ and then stimulated with LPS $(10 \mu \mathrm{g} / \mathrm{ml})$ for 24 h. The amount of nitrite, a stable metabolite of NO, was used as the indicator of NO production in the medium. Among the isolated triterpenes, it has been described that lupenone (4) reduced $\mathrm{NO}$ production with an $\mathrm{IC}_{50}$ value of $10.81 \mu \mathrm{M}$, in LPS-stimulated RAW 264.7 cells [25], and was included as the positive control. The experimental results showed that NO level was increased in LPS-stimulated RAW cells, and this effect was decreased significantly by treatment with compounds 1-6 $(P<0.001)$ (Fig. 3). The $\mathrm{IC}_{50}$ values are gathered in Table 2 and it can be seen that $\alpha$-amyrin (6) was the most active compound with $\mathrm{IC}_{50}$ value of $8.98 \mu \mathrm{M}$, while 3-epilupeol formiate (1) was the less active one with $\mathrm{IC}_{50}$ value of $43.31 \mu \mathrm{M}$.

Evaluation of the inhibition of the enzymes COX-1, COX-2 and $\mathrm{PLA}_{2}$ showed that neither of the natural triterpenes inhibited COX-1 when evaluated at $70 \mu \mathrm{M}$, and only compounds 2 and 3 inhibited by $62.85 \%$ and 73.28 $\%$ respectively the activity of COX-2 at $70 \mu \mathrm{M}$. Evaluation of the inhibition of $\mathrm{PLA}_{2}$ showed that all compounds inhibited moderately this enzyme 2 (17.27\%), 3 (12.6\%), 4 (7.12\%), 5 (16.6\%), and 6 (9.31\%) at $70 \mu \mathrm{M}$.

\section{Discussion}

The resin of $B$. copallifera, known as "copal ancho", has been used to treat various inflammatory diseases 

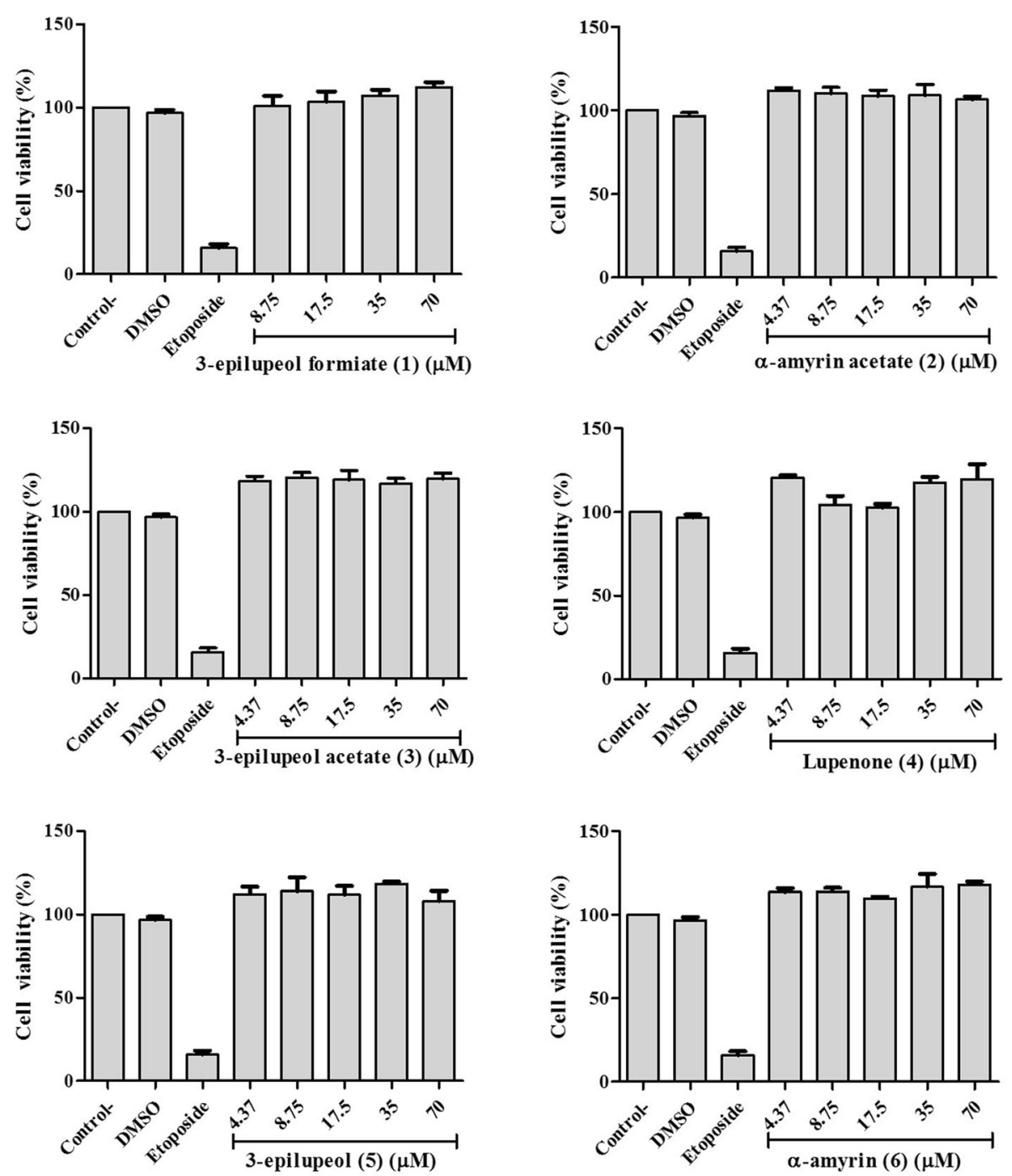

Fig. 2 Effect of natural triterpenes $\mathbf{1 - 6}$ on the viability of LPS-stimulated RAW 264.7 cells. The values are expressed as the mean \pm SD of three independent experiments

$[10,11,13]$. Despite the importance of this plant species, there is little knowledge about the anti-inflammatory activity and the potential anti-inflammatory components. In this work, we demonstrated that the total resin of $B$. copallifera inhibited the TPA-induced edema on mice with $\mathrm{ID}_{50}$ value of $0.7071 \mathrm{mg} /$ ear. Phytochemical analysis of this resin allowed the isolation of six triterpene compounds which were characterized as 3-epilupeol formiate (1), $\alpha$-amyrin acetate (2), 3-epilupeol acetate (3), lupenone (4), 3-epilupeol (5) and $\alpha$-amyrin (6). Pentacyclic triterpenes are commun metabolites in the resins of Bursera species. B. delpechiana contains principally triterpenes with ursan skeleton, including $\alpha$-amyrin [26]; the stem of B. graveolens contain lignans, and the triterpenes lupeol and epilupeol [27], and the leaves produce flavonoids and the triterpene $\alpha$-amyrin [28]; B. simaruba, synthesize lupene-related pentacyclic triterpenes such as lup-20(29)en-3 $\beta, 23$-diol, lupeol, epilupeol, epiglutinol and $\alpha$-amyrin [29-31]. Finally, B. microphylla was reported to have malabaricane type triterpenes [32]. Previous studies had already described the existence of lupeol and lupenone on the resin of $B$. copallifera, collected in Guerrero state, México [33], but this is the first report on the presence of triterpenes 1-3 and 5-6 in the resin of B. copallifera, where 3-epilupeol (59.75\%) and $\alpha$-amyrin (21.1\%) were identified as the major components. The high yields of 5 and $\mathbf{6}$ are in accordance with those described for the commercial Mexican copal Sonora resin in where these triterpenes are in 73 and $21 \%$ yields respectively [34].

Among the isolated triterpenes, in recent years $\alpha$-amyrin (6) has attracted much interest because its multiple pharmacological effects, principally as antinociceptive, 

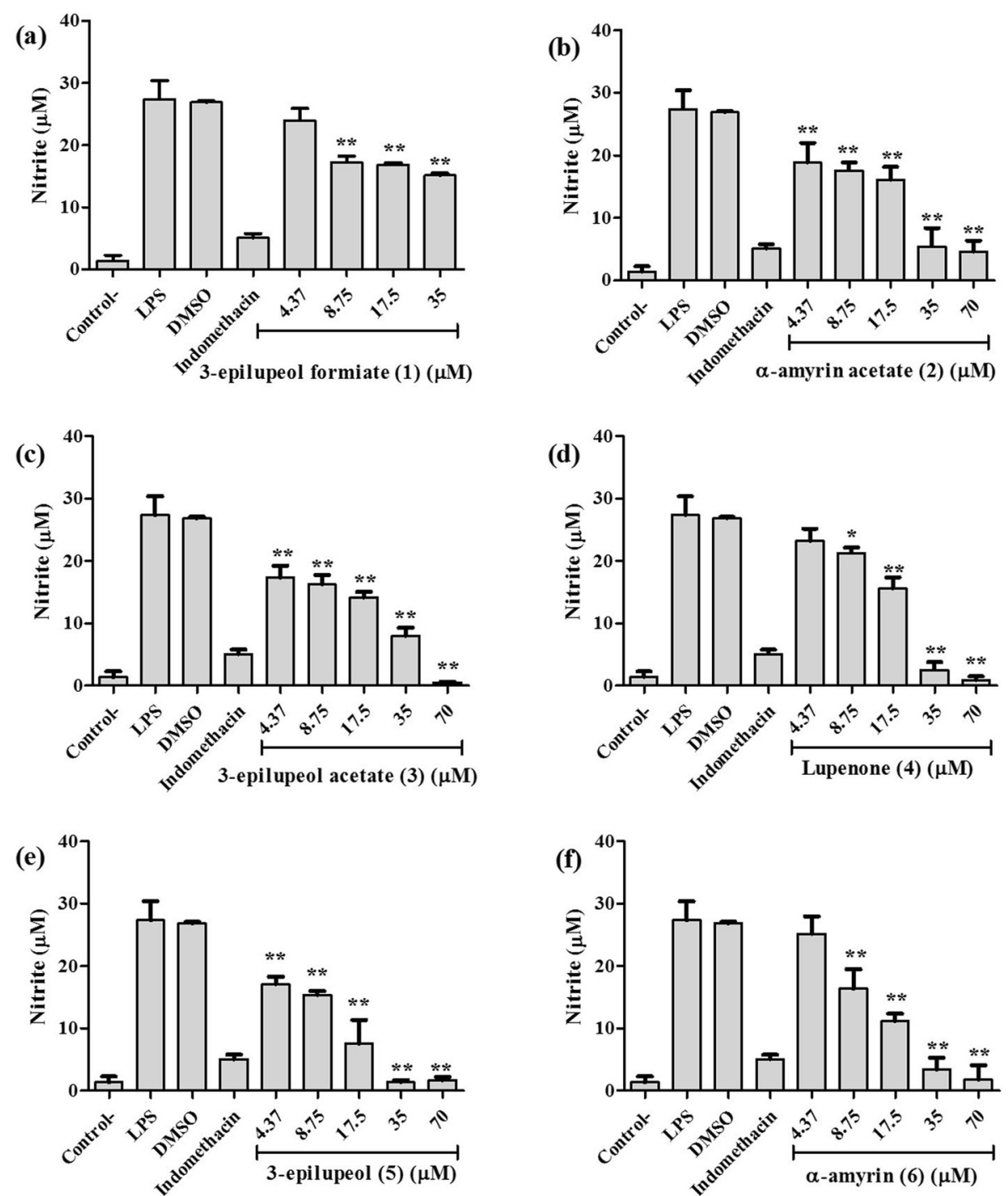

Fig. 3 Effect of the isolated triterpenes on NO production in LPS-stimulated RAW 264.7 cells. (a) 3-epilupeol formiate, (b) a-amyrin acetate, (c) 3-epilupeol acetate, (d) lupenone, (e) 3-epilupeol, and (f) a-amyrin. The nitrite values are the mean \pm SD from three independent experiments. Significance was determined by one-way ANOVA ( ${ }^{*} P<0.01$; ${ }^{* *} P<0.001$ compared to LPS)

Table 2 Effect of the natural triterpenes $\mathbf{1 - 6}$ on NO production on RAW 264.7 macrophages

\begin{tabular}{lc}
\hline Compound & $\mathrm{NO}^{\mathrm{a}}$ \\
\hline 3-epilupeol formiate (1) & $43.31 \pm 2.60$ \\
a-amyrin acetate (2) & $22.57 \pm 1.19$ \\
3-epilupeol acetate (3) & $31.13 \pm 1.25$ \\
Lupenone (4) & $20.80 \pm 1.07$ \\
3-epilupeol (5) & $15.50 \pm 1.14$ \\
a-amyrin (6) & $8.98 \pm 1.73$ \\
Indomethacin $\left(83.8^{\circ} \mu \mathrm{M}\right)$ & $54.69 \pm 10.34$
\end{tabular}

a Data represent the means \pm SD $(n=3)$. Values are an average of three independent experiments performed in triplicate $(p<0.001)$ anti-inflammatory, antipruritic, hepatoprotective, antihyperglycemic, and it has been demonstrated that the topical anti-inflammatory activity involve the inhibition of PGE2 level via inhibition of the COX-2 expression [35, 36]. Epilupeol (5), however, has been less studied, although its antiinflammatory [37], antitubercular [38], and cytotoxic [39] activities have been described. 3-epilupeol acetate (3) has been reported to have $\alpha$-glucosidase inhibitory activity [40]. 3-epilupeol formiate (1), was reported as constituent of Boswellia carterii [18], and until now there is not reports about its biological activity.

Except for compounds $\mathbf{3}$ and $\mathbf{6}$, all the triterpenes showed marked anti-inflammatory activity when tested in the TPA-induced ear edema in mice. Triterpenes with 
the lupane skeleton showed the best activity, being 3-epilupeol $\left(\mathbf{5}, \mathrm{ID}_{50}=0.83 \mu \mathrm{mol} / \mathrm{ear}\right)$, together with its 3 -formyl ester $\left(1, \mathrm{ID}_{50}=0.96 \mu \mathrm{mol} / \mathrm{ear}\right)$ the most active compounds. 3-epilupeol acetate $(3)\left(\mathrm{ID}_{50}=>2.13 \mu \mathrm{mol}\right)$, and $\alpha$-amyrin $(6)\left(\mathrm{ID}_{50}=>2.34 \mu \mathrm{mol}\right)$ were the less active. In contrast, $\alpha$-amyrin acetate (2) was active with $\mathrm{ID}_{50}$ value of $1.17 \mu \mathrm{mol} /$ ear. A survey of the literature, about the anti-inflammatory properties of the isolated compounds, revealed that compounds $\mathbf{2}, \mathbf{4 , 5}$ and $\mathbf{6}$ were previously evaluated in the TPA-induced edema in mice $[37,41-44]$. The results obtained in this work matched well with those described, except for $\alpha$-amyrin (6) probably because its poor solubility.

Further, we evaluated the effects of these natural triterpenes on the production of NO in RAW 264.7 macrophages. For comparison, the activity of lupenone (4) was included as positive control. The cytotoxicities of compounds in RAW 264.7 cells were also assessed using MTS assay [45]. In all cases, the natural triterpenes exhibited potent NO production inhibitory activities, and did not affect the cell viabilities in either the presence or absence of LPS, even at a concentration of $70 \mu \mathrm{M}$, indicating no significant effect of exposure of the cells to LPS at the concentrations used (Fig. 2). The results indicate that all compounds are effective inhibitors of LPSinduced NO production in these cells. Indeed, as is shown in Fig. 3, the production of NO was markedly elevated in response of LPS. However, the application of the triterpenes 1-6 inhibited the production of NO by LPS in a concentration-dependent manner, and as shown in Table 2, compounds 2, 4, 5 and $\mathbf{6}$ exhibited inhibitory potency with $\mathrm{IC}_{50}$ values of $22.47,20.8,15.5$ and $8.98 \mu \mathrm{M}$, respectively. Compounds $\mathbf{1}$ and $\mathbf{3}$ displayed moderate effects with $\mathrm{IC}_{50}$ values of 43.31 and 31.13 $\mu \mathrm{M}$, respectively. Although lupenone (4) inhibited NO production at $10.81 \mu \mathrm{M}$ in the previous report [25], the $\mathrm{IC}_{50}$ value obtained in our assay $(20.8 \mu \mathrm{M})$ was of equivalent order of magnitude.

3-epilupeol (5) $\left(\mathrm{IC}_{50}=15.5 \mu \mathrm{M}\right)$ showed higher potency than lupeol $\left(\mathrm{IC}_{50}=64.65 \mu \mathrm{M}\right)$ isolated from Pueraria lobata roots [25], and lesser than the lanostantype triterpene butyl lucidenate $\mathrm{Q}\left(\mathrm{IC}_{50}=4.3 \mu \mathrm{M}\right)$, isolated from Ganoderma lucidum [46]. The best inhibitor was $\alpha$-amyrin with $\mathrm{IC}_{50}$ value of $8.98 \mu \mathrm{M}$, better than that displayed by ursolic acid with $9.3 \% \mathrm{NO}$ production inhibition with $43.8 \%$ cell viability at $10 \mu \mathrm{M}$ [47].

Evaluation of the inhibition in vitro of the enzymes COX-1, COX-2 and PLA A $_{2}$ activities showed that neither of the natural triterpenes inhibited COX-1 when evaluated at $70 \mu \mathrm{M}$, and only compounds 2 and 3 inhibited by $62.85 \%$ and $73.28 \%$ respectively the activity of COX2 at $70 \mu \mathrm{M}$. 3-epilupeol (3) showed the highest inhibition of COX-2. Lupenone (4) has been described that inhibit the activity of COX-2 by $40 \%$ at $100 \mu \mathrm{g} / \mathrm{mL}$ [48], while in our assay, lupenone (4) displayed $9.8 \%$ inhibition at $70 \mu \mathrm{M}$. The inhibitory effects of these compounds were compared with selective COX-1 inhibitor, SC-560 (90\% inhibition at $3.3 \mu \mathrm{M})$ and selective COX-2 inhibitor, DuP-697 ( $>90 \%$ inhibition at $3 \mu \mathrm{M}$ ) provided by the kit assay. Evaluation of the inhibition of $\mathrm{PLA}_{2}$ showed that all compounds inhibited moderately this enzyme 2 (17.27 \%), 3 (12.6 \%), 4 (7.12\%), 5 (16.6\%), and $6(9.31 \%)$ at $70 \mu \mathrm{M}$, while the positive control palmitoyltrifluoromethylketone produced $25 \%$ inhibition of $\mathrm{PLA}_{2}$ at a concentration of $4 \mu \mathrm{M}$ [13].

Accumulating evidence has indicated that NO is well known for its involvement in the development of inflammation $[49,50]$. NO is an important intra- and intercellular signaling molecule in cardiovascular, nervous, and immunological systems. NO is involved in various biological reactions including vasorelaxation, inhibition of platelet aggregation, neurotransmission, inflammation, and immunoregulation [51, 52]. Therefore, identifying new agents capable of lowering the production of this proinflammatory agent is regarded as an essential requirement for the alleviation of a number of inflammation-related disorders attributed to macrophage activation [53]. Similarly, COX and $\mathrm{PLA}_{2}$ are key enzymes in the synthesis of inflammatory prostaglandins which contributes to pathogenesis of various inflammatory diseases, edema, angiogenesis, invasion, and growth of tumor. COX-1 is a constitutively expressed enzyme with general housekeeping functions. COX-2 is an inducible enzyme that catalyzes biosynthesis of PGE2 [54, 55]. PLA 2 catalyze the hydrolysis of the phospholipid sn-2 ester bond, generating a free fatty acid and a lysophospholipid. The $\mathrm{PLA}_{2}$ reaction is the primary pathway through which arachidonic acid (AA) is liberated from phospholipids. Free $\mathrm{AA}$ is the precursor of the eicosanoids, which include the prostaglandins, generated through the COX reaction, and the leukotrienes, generated through the lipoxygenase reaction [56].

\section{Conclusions}

In conclusion the total resin of B. copallifera possess significant and promising anti-inflammatory activity. In this study, we showed that in LPS-stimulated macrophages, the isolated compounds 1-6 dose-dependently inhibited $\mathrm{NO}$ and triterpenes $\alpha$-amyrin acetate (2) and 3-epilupeol acetate (3) inhibited the activity of COX-2, while all of them showed moderate inhibitory activity of $\mathrm{PLA}_{2}$ enzyme, suggesting that this was the mechanism underlying the observed anti-inflammatory activity observed in vivo.

The study also signifies that isolated constituents could be responsible, at least in part, for its anti-inflammatory activity. The study verifies traditional use of $B$. copallifera for the treatment of rheumatism, asthma, and other inflammatory disorders. 


\section{Abbreviations}

\%: Percentage; ${ }^{13} \mathrm{C}$ : 13 -carbon isotope; ${ }^{1} \mathrm{H}$ : Proton; ${ }^{1} \mathrm{H}-{ }^{1} \mathrm{H}$ gCOSY: Gradientselected homonuclear correlation spectroscopy; ANOVA: Analysis of variance; $\mathrm{CDCl}_{3}$ : Deuterated chloroform; $\mathrm{CH}_{2} \mathrm{Cl}_{2}$ : Dichloromethane;

$\mathrm{CH}_{3} \mathrm{CN}: \mathrm{H}_{2} \mathrm{O}$ : Acetonitrile/wáter; $\mathrm{CO}_{2}$ : Carbon dioxide; DMEM/F12: Dulbecco's modified eagle's medium/nutrient mixture F-12; DMSO: Dimethyl sulfoxide; FABMS: Fast atom bombardment mass spectrometry; FBS: Fetal bovine serum; gHSQC: Gradient-selected heteronuclear single-quantum correlation; gradient-selected heteronuclear multiple bond correlation; h: Hour; HPLC: High performance liquid chromatography; ID 50 : Median inhibitory dose $\mathrm{IC}_{50}$ : half inhibitory concentration; L: Liter; LPS: Lipopolysaccharide; Mg: Milligramme; MHz: Megahertz; min: Minute; mL: Milliliter; MTS: 3-(4,5dimethyl-2-yl)-5-(3-carboxymethoxyphenyl)-2-(4-sulfophenyl)-2H-tetrazolium, inner salt; $\mathrm{NaNO}_{2}$ : Sodium nitrite; $\mathrm{nm}$ : Nanometer; NMR: Nuclear magnetic resonance; NO: Nitric oxide; NOESY: Nuclear Overhauser effect spectroscopy; $\mathrm{OD}_{540}$ : Optical density at $540 \mathrm{~nm}$; P: Error probability; PGE2: Prostaglandin E2; RP-18e: Reverse phase-18; SD: Standard deviation; TLC: Thin layer chromatography; v/v: Volume/volume; $\mu \mathrm{g}$ : Microgramme; $\mu \mathrm{L}$ : Microliter; $\mu \mathrm{M}$ : Micromolar;

\section{Acknowledgment}

This research was supported in part by CONACyT (Grants CB 240801 and LN251613). ARE (No. 253953) and AMM are grateful to CONACyT for providing fellowship.

\section{Funding}

The authors declare that they have received funding by Consejo Nacional de Ciencia y Tecnología (CONACyT).

\section{Availability of data and materials}

All data and materials are contained and described within the manuscript, except the spectroscopic data of isolated compounds, which are available at request.

\section{Authors' contributions}

MLG-R conducted the animal experiments and analyzed the data. AR-E and VR-L performed phytochemical and HPLC analyses of the resin, and participated in the correction of the manuscript. JG-C and AM-M conducted the in vitro studies and analyzed data. LA and SM participated in design of the study and preparation of the manuscript. All the authors read and approved the final manuscript.

\section{Competing interests}

The authors declare that there is not conflict of interests regarding the publication of this paper.

\section{Consent for publication}

Not applicable.

\section{Ethics approval and consent to participate}

This study was approved by the Comité de Experimentación del Bioterio of the Universidad Autónoma del Estado de Morelos (BIO-UAEM) (Approval number: BIO-UAEM: 009:2013.

\section{Author details}

${ }^{1}$ Centro de Investigaciones Químicas-IICBA, Universidad Autónoma del Estado de Morelos, Avenida Universidad 1001, Chamilpa, Cuernavaca, Morelos 62209, Mexico. ${ }^{2}$ Facultad de Farmacia, Universidad Autónoma del Estado de Morelos, Avenida Universidad 1001, Chamilpa, Cuernavaca, Morelos 62209, Mexico.

\section{Received: 10 April 2016 Accepted: 11 October 2016} Published online: 26 October 2016

\section{References}

1. Gámez N, Escalante T, Espinosa D, Eguiarte LE, Morrone JJ. Temporal dynamics of areas of endemism under climate change: a case study of Mexican Bursera (Burseraceae). J Biogeogr. 2014;41:871-81.

2. Becerra JX. Timing the origin and expansion of the Mexican tropical dry forests. PNAS. 2005;102:10919-23.
3. Rzedowski J, Medina R, Calderón G. Inventario del conocimiento taxonómico, así como de la diversidad y del endemismo regionales de las especies mexicanas de Bursera (Burseraceae). Acta Bot Mex. 2005;70:85-111.

4. Case RJ, Tucker AO, Maciarello MJ, Wheeler KA. Chemistry and Ethnobotany of Commercial Incense Copals, Copal Blanco, Copal Oro, and Copal Negro, of North America. Econ Bot. 2003;57:189-202.

5. Becerra JX. Evolution of Mexican Bursera (Burseraceae) inferred from ITS, ETS, and $5 S$ nuclear ribosomal DNA sequences. Mol Phylogenet Evol. 2003;26:300-9.

6. Linares E, Bye R. El copal en México. CONABIO. Biodiversitas. 2008;78:8-11.

7. Purata SE, editor. Uso y manejo de los copales aromáticos: resinas y aceites. México: CONABIO/RAISES; 2008.

8. Martinez M. Plantas útiles de la flora Mexicana. Primera edición. México: Ediciones Botas: 1959

9. Argueta AL, Cano MR. Atlas de las Plantas de la Medicina Tradicional Mexicana. México: Instituto Nacional Indigenista; 1994.

10. Monroy C, Castillo P. Plantas medicinales utilizadas en el estado de Morelos. México: Centro de Investigaciones Biológicas/Universidad Autónoma del Estado de Morelos; 2007

11. Dorado O, Maldonado B, Arias D, Sorani V, Ramírez R, Leyva E, Valenzuela D. Programa de Conservación y Manejo Reserva de la Biosfera Sierra de Huautla. Comisión Nacional de Areas Naturales Protegidas: México; 2005.

12. Lautié E, Quintero R, Fliniaux MA, Villarreal ML. Selection methodology with scoring system: Application to Mexican plants producing podophyllotoxin related lignans. J Ethnopharmacol. 2008;120:402-12.

13. Columba-Palomares MC, Villareal ML, Acevedo ME, Marquina S, Alvarez L, Rodríguez-López V. Anti-inflammatory and cytotoxic activities of Bursera copallifera. Pharmacogn Mag. 2015;11:S322-8.

14. Fürstenberger $\mathrm{G}$, Richter $\mathrm{H}$, Fusenig NE, Marks F. Arachidonic acid and prostaglandin $\mathrm{E} 2$ release and enhanced cell proliferation induced by the phorbol ester TPA in a murine epidermal cell line. Cancer Lett. 1981;11:191-8.

15. Ashendel $\mathrm{CL}$, Boutwell RK. Prostaglandin $\mathrm{E}$ and $\mathrm{F}$ levels in mouse epidermis are increased by tumor-promoting phorbol esters. Biochem Biophys Res Commun. 1979;90:623-7.

16. Salinas R, Arellano-García J, Perea-Arango I, Alvarez L, Garduño-Ramírez ML, Marquina S, Zamilpa A, Castillo-España P. Production of the AntiInflammatory Compound 6-0-Palmitoyl-3-O- $\beta$-D-glucopyranosylcampesterol by Callus Cultures of Lopezia racemosa Cav. (Onagraceae). Molecules. 2014; 19:8679-90.

17. Yang G, Lee K, Lee M, Ham I, Choi H-Y. Inhibition of lipopolysaccharideinduced nitric oxide and prostaglandin E2 production by chloroform fraction of Cudrania tricuspidata in RAW 264.7 macrophages. BMC Complement Alter Med. 2012;12:250

18. Morikawa T, Oominami H, Matsuda H, Yoshikawa M. New terpenoids, olibanumols D-G, from traditional Egyptian medicine olibanum, the gumresin of Boswellia carterii. J Nat Med. 2011:65:129-34.

19. Feleke S, Brehane A. Triterpene compounds from the latex of Ficus sur I. Bull Chem Soc Ethiop. 2005;19:307-10.

20. Yessoufou K, Elansary HO, Mahmoud EA, Skalicka-Wozniak K. Antifungal, antibacterial and anticancer activities of Ficus drupacea L. steam bark extract and biologically active isolated compounds. Ind Crops Prod. 2015;74:752-8.

21. Na M, Kim BY, Osada H, Ahn JS. Inhibition of protein tyrosine phosphatase $1 \mathrm{~B}$ by lupeol and lupenone isolated from Sorbus commixta. J Enzim Inhib Med Chem. 2009:24:1056-9.

22. Alam F, Rahman MS, Alam MS, Hossain MK, Hossain MA, Rashid MA. Phytochemical and Biological investigations of Phoenix paludosa Roxb. Daka Univ J Pharm Sci. 2009;8:7-10.

23. de Souza AD L, da Rocha AF I, Pinheiro MLB, Andrade CH, Galotta ALQ, Dos Santos MSS. Constituyentes Químicos De Gustavia Augusta L. (Lecythidaceae). Quim Nova. 2001;24:439-42.

24. Hernández L, Palanzon J, Navarro-Ocaña A. The Pentacyclic Triterpenes a, $\beta$ amyrins: A Review of Sources and Biological Activities, Phytochemicals - A Global Perspective of Their Role in Nutrition and Health, DrVenketeshwer Rao (Ed.). In Tech. 2012;487-502. Available from: http://www.intechopen. com/books/phytochemicals-a-global-perspective-of-their-role-innutritionandhealth/the-pentacyclic-triterpenes-amyrins-a-review-of-sourcesand-biological-activities.

25. Jin SE, Son YK, Min BS, Jung HA, Choi JS. Anti-inflammatory and Antioxidant Activities of Constituents Isolated from Pueraria lobata Roots. Arch Pharm Res. 2012;35:823-37.

26. Syamasundar KV Mallavarapu GR, Krishna EM. Triterpenoids of the Resin of Bursera delpechiana. Phytochemistry. 1991;30:362-3. 
27. Nakanishi T, Inatomi Y, Murata H, Shigeta K, lida N, Inada A, Murata J, Perez MA, linuma M, Tanaka T, Tajima S, Oku N. A New and known Cytotoxic Aryltetralin-Type Lignans from Steams of Bursera graveolens. Chem Pharm Bull. 2005:53:229-31.

28. Nakanishi $T$, Inatomi $Y$, Arai $S$, Yamada T, Fukatsu $H$, Murata $H$, Inada A, Matsuura N, Ubukata M, Murata J, linuma M, Perez MA, Tanaka T. New Luteolin 3'-O-Acylated Rhamnosides from Leaves of Bursera graveolens. Heterocycles. 2003;60:2077-83.

29. Peraza-Sánchez SR, Salazar-Aguilar NE, Peña Rodríguez LM. A New Triterpene from the Resin of Bursera simaruba. J Nat Prod. 1995;58:271-4.

30. Álvarez AL, Habtemariam S, Parra F. Inhibitory effects of Lupene-derived Pentacyclic Triterpenoids from Bursera simaruba on HSV-1 and HSV-2 in vitro replication. Nat Prod Res. 2015;29:2322-7.

31. Carretero ME, López-Pérez JL, Abad MJ, Bermejo P, Tillet S, Israel A, Noruega-P B. Preliminary study of the Anti-inflammatory Activity of hexane extract and fractions from Bursera simaruba (Linneo) Sarg. (Burceraceae) Leaves. J Ethnopharmacol. 2008;116:11-5.

32. Curini M, Di Sano C, Zadra C, Gigliarelli G, Rascón-Valenzuela LA, Robles RE Marcotullio MC. Diterpenoids and Triterpenoids from the Resin of Bursera microphylla and Their Cytotoxic Activity. J Nat Prod. 2015;78:1184-8.

33. Lucero-Gómez P, Mathe C, Vieillescazes C, Bucio L, Belio I, Vega R. Analysis of Mexican reference standards for Bursera spp. resins by Gas Chromatography-Mass Spectrometry and application to archaeological objects. J Archaeol Sci. 2014;41:679-90.

34. Hernández-Vázquez L, Mangas S, Palazon J, Navarro-Ocaña A. Valuable medicinal plants and resins: Commercial phytochemicals with bioactive properties. Ind Crops Prod. 2010;31:476-80.

35. Otuki MF, Vieira-Lima F, Malheiros A, Yunes RA, Calixto JB. Topical antiinflammatory effects of the ether extract from Protium kleinii and alphaamyrin pentacyclic triterpene. Eur J Pharmacol. 2005;507:253-9.

36. Medeiros R, Otuki MF, Avellar MCW, Calixto JB. Mechanisms underlying the inhibitory actions of the pentacyclic triterpene a-amyrin in the mouse skin inflammation induced by phorbol ester 12-0-tetradecanoylphorbol-13acetate. Eur J Pharmacol. 2007;559:227-35.

37. Yasukawa K, Yu SY, Yamanouchi S, Takido M, Akihisa T, Tamura T. Some lupane-type triterpenes inhibit tumor promotion by 12-0-

tetradecanoylphorbol-13-acetate in two-stage carcinogenesis in mouse skin. Phytomedicine. 1995:4:309-13.

38. Guzman JD, Gupta A, Bucar F, Gibbons S, Bhakta S. Antimycobacterials from natural sources: ancient times, antibiotic era and novel scaffolds. Front Biosci. 2012;17:1861-81.

39. Puapairoj P, Naengchomnong W, Kijjoa A, Pinto MM, Pedro M, Nascimento MSJ, Silva AMS, Herz W. Cytotoxic activity of lupane-type triterpenes from Glochidion sphaerogynum and Glochidion eriocarpum two of which induce apoptosis. Planta Med. 2005;71:208-13.

40. Kiem PV, Minh CV, Nhiem NX, Yen PH, Anh HLT, Cuong NX, Tai BH, Quang TH, Hai TN, Kim SH, Kwon S, Lee Y, Kim YH. Chemical constituents of Ficus drupaceae leaves and their a-glucosidase inhibitory activities. Bull Korean Chem Soc. 2013;34:263-6.

41. Akihisa T, Kojima N, Kikuchi T, Yasukawa K, Tokuda H, Masters ET, Manosroi A, Manosroi J. Anti-Infl ammatory and Chemopreventive Effects of Triterpene Cinnamates and Acetates from Shea Fat. J Oleo Sci. 2010;59:273-80.

42. Bhandari P, Patel NK, Bhutani KK. Synthesis of new heterocyclic lupeol derivatives as nitric oxide and pro-inflammatory cytokine inhibitors. Bioorg Med Chem Lett. 2014:24:3596-9.

43. Yasukawa K, Matsubara H, Sano Y. Inhibitory effect of the flowers of artichoke (Cynara cardunculus) on TPA-induced inflammation and tumor promotion in two-stage carcinogenesis in mouse skin. J Nat Med. 2010;64:388-91.

44. Okoye NN, Ajaghaku DL, Okeke HN, lodigwe EE, Nworu CS, Okoye FBC. Beta-Amyrin and alpha-amyrin acetate isolated from the stem bark of Alstonia boonei display profound anti-inflammatory activity. Pharm Biol. 2014:52:1478-86.

45. Sittampalam GS, Coussens NP, Nelson H, Arkin M, Auld D, Austin C, Bejcek B, Glicksman M, Inglese J, Iversen PW, Li Z, McGee J, McManus O, Minor L, Napper A, Peltier JM, Riss T, Trask OJ, Weidner J. Assay Guidance Manual. In: Lilly E, Company and the National Center for Advancing Translational Sciences. 2004. http://www.ncbi.nlm.nih.gov/books/NBK53196/. Accessed 12 Oct 2015.

46. Tung NT, Cuong TD, Hung TM, Lee JH, Woo MH, Choi JS, Kim J, Ryu SH, Min BS. Inhibitory effect on NO production of triterpenes from the fruiting bodies of Ganoderma lucidum. Bioorg Med Chem Lett. 2013;23:1428-32.
47. Kwon TH, Lee B, Chung SH, Kim D-H, Lee YS. Synthesis and NO Production Inhibitory Activities of Ursolic Acid and Oleanolic Acid Derivatives. Bull Korean Chem Soc. 2009;30:119-23.

48. Zhang C, Aldosari SA, Vidyasagar PSPV, Nair KM, Nair MG. Antioxidant and Anti-inflammatory Assays Confirm Bioactive Compounds in Ajwa Date Fruit. J Agric Food Chem. 2013;61:5834-40.

49. Roberts IC, Fon J, Uylaki W, Cummins AG, Barry S. Cells, cytokines and inflammatory bowel disease: a clinical perspective. Expert Rev Gastroenterol Hepatol. 2011;5:703-16.

50. Sautebin L. Prostaglandins and nitric oxide as molecular targets for antiinflammatory therapy. Fitoterapia. 2000;71:S48-57.

51. Kroncke KD, Fehsel K, Kolb-Bachofen V. Inducible nitric oxide synthase in human diseases. Clin Exp Immunol. 1998;113:147-56.

52. Hobbs AJ, Higgs A, Moncada S. Inhibition of nitric oxide synthase as a potential therapeutic target. Annu Rev Pharmacol Toxicol. 1999:39:191-220.

53. Dittrich A, Hessenkemper W, Schaper F. Systems biology of IL-6, IL-12 family cytokines. Cytokine Growth Factor Rev. 2015;26:595-602.

54. Simmons DL, Botting RM, Hla T. Cyclooxygenase Isozymes: The Biology of Prostaglandin Synthesis and Inhibition. Pharmacol Rev. 2004;56:387-437.

55. Sarkar FH, Adsule S, Li Y, Padhye S. Back to the future: COX-2 inhibitors for chemoprevention and cancer terapy. Mini Rev Med Chem. 2007;7:599-608.

56. Balsinde J, Winstead MV, Dennis EA. Phospholipase A2 regulation of arachidonic acid mobilization. FEBS Lett. 2002;531:2-6.

\section{Submit your next manuscript to BioMed Central and we will help you at every step:}

- We accept pre-submission inquiries

- Our selector tool helps you to find the most relevant journal

- We provide round the clock customer support

- Convenient online submission

- Thorough peer review

- Inclusion in PubMed and all major indexing services

- Maximum visibility for your research

Submit your manuscript at www.biomedcentral.com/submit
) Biomed Central 